\title{
SHIPBOARD UNION REPRESENTATION IN THE BRITISH MERCHANT NAVY
}

Shop stewards, or other forms of workshop representation, are a common feature of British industry. It is not known for certain how many such shop floor representatives are active; estimates vary between 90,000 and $200,000,1$ "the truth is probably somewhere between these two figures". ${ }^{2}$ What is certain, however, is that the great majority of industrial workers, particularly in large-scale industry, have recourse to lay trade union representation for the settlement of shop floor grievances. Often such representatives are "the union" for the ordinary workman who does not come into contact with full-time union officers. "For the great majority of British trade unionists the workplace representative is their only direct personal link with their union." 3 He also provides a front-line defence against the arbitrary use of authority by management. If no shop steward existed, managerial authority, unchecked by the countervailing power of shop floor representatives, would be open to abuse. If such managerial authority was also supported by a system of legal powers which further strengthened its position, it would make possible "the use of penal sanctions to compel acceptance of working conditions which free agents would not endure". "Such was the case in the British Merchant Navy until less than five years ago.

In this article I intend to analyse the struggle of British merchant seamen to obtain some form of shipboard union representation, to make a case study of events leading to the acceptance of a scheme for shipboard liaison representatives, and to make a critical assessment of

${ }^{1}$ H. Clegg, et al., Trade Union Officers, Blackwell, 1961, p. 153, and TUC Report: 1960, p. 128.

2 Royal Commission on Trade Unions and Employers' Associations, Research Paper (1), HMSO, 1966, p. 5.

Training Shop Stewards, Trades Union Congress, 1968, p. 4.

4 J. Kinahan, Unpublished Evidence to the Committee of enquiry into certain matters concerning the Shipping Industry, Chairman Lord Pearson, 1966. 
the scheme which was finally agreed between the seamen's union, the National Union of Seamen, and the shipowners in the British Shipping Federation. Before proceeding to this particular issue it may be useful to say something more general about the relationship between shop stewards and trade union organisations within British industry.

The question of the shop stewards' place in industry is a major industrial problem. If one is to believe reports in the popular press they are the bete noire of employers and a major cause of industrial unrest. Recent studies have thrown a little more light and rather less prejudice on the subject. They have also clarified some of the problems involved. Research Paper (1), to the Royal Commission on Trade Unions and Employers' Associations, on The Role of Shop Stewards in British Industrial Relations, has this to say on the subject:

"The general view of the shop steward supported by existing studies sees him as essentially a shop floor bargainer using every opportunity available to him to try to satisfy members' demands. If necessary he is ready to circumvent established procedures and union rules in pursuit of this objective. His activities, from the Management viewpoint, appear to involve a constant challenge of their prerogatives and authority. To meet such a challenge they must adopt a more systematic and planned response to shop floor demands. Unions too are challenged by the growth in shop steward influence and power. They need active and loyal shop stewards to give meaning to union membership at shop floor level, but must remain alive to the potential dangers of relying on semi-independent lay officials, who create personal and multi-union loyalties among their rank and file."1

The major problems identified in this paragraph are on the one hand the need for shop stewards to "give meaning to union membership at shop floor level", particularly in the challenge to managerial prerogatives and authority, whilst at the same time the unions must be "alive to the potential dangers of relying on semi-independent lay officials". In short, there is a need for shop stewards but they must be subjected to official union control.

The recognition of the need for shop stewards was, in most cases, a recognition "after the fact".

"Throughout the history of trade unions the basic unit of organisation has been the branch and not the place of work. The structure of unions developed from the branch, and it was not until the

1 Research Paper (1), p. 4. 
higher stages of conference, national executive, and district committees were complete that attention was turned to improving and systematizing organisation at the place of work."1

By the time official union thinking had come round to the need for organisation at the workplace, in many cases it already existed. Informal unionism had filled the gap left by official unionism pre-occupied with national negotiations. Full employment since the Second World War strengthened the position of shop stewards in plant-level negotiations, and this increased bargaining power, outside the orbit of official unionism, gave the shop steward a unique place within the industrial relations system. It was government concern with the question of "wage drift", and the inflationary consequences of plant bargains unrelated to productivity, that caused official policy and trade unions to turn their attention to the problem of controlling shop floor negotiators. For example the Royal Commission on Trade Unions and Employers' Associations made a number of recommendations intended to control the activities of shop stewards, to bring them more effectively into the official union orbit.

Paragraph 1078: "Trade unions should provide constitutionally recognised committees to perform many of the functions now carried out by unofficial shop stewards' 'combine' committees."

Paragraph 1079: "The process of union government should be altered to accommodate shop stewards and work groups more adequately. It is desirable for union branch organisation to be based on factories and for branch meetings to be held at the place of work. This will require the co-operation of employers. Union rules relating to shop stewards should be revised in relation to such matters as elections, terms of office, the filling of casual vacancies, the bounds of the shop steward's jurisdiction, his relations with union officials and his place in the union's organisation."2

These recommendations from the Royal Commission are explicit recognition of the power of informal workplace unionism in conditions of full employment, and of the need for the bureaucratisation of that power within the formal union structure. Shop floor representatives have been a "rogue" influence on the industrial scene, justifying their position by success in challenging management and winning improved

1 British Trade Unionism, Political and Economic Planning, 1955. Quoted by A. J. M. Sykes, The Shop Stewards' Place in Industry.

2 Report of the Royal Commission on Trade Unions and Employers' Associations 1965-1968, Cmnd 3623, pp. 271-272. 
earning power for the workers they represent, but, outside official union control. Workers without such representatives, having to rely on official union representation, compared unfavourably in both wage increases and the power relationship with management. This was the case for the Britisch merchant seamen. The need to challenge shipboard authority, and the desire to keep pace with the earnings of shore workers, were basic factors behind the internal pressure within the National Union of Seamen for a system of shipboard union representation. These same factors and the problems of control over shipboard representatives also provide the key to the opposition of union officials, and the antagonism of shipowners, towards the idea.

The men of the British Merchant Navy, absent from the United Kingdom for long periods "on voyage" had little opportunity for trade union activity, or contact with shore-based full-time union officers. Until 1965 there was no union representation at the workplace, on board ship. Over many years there was internal pressure within the National Union of Seamen for some form of Union supported shipboard representation. Resolutions on the subject appear on the agenda of the Union's Annual General Meetings from 1943 to 1949, and again in 1951, 1956 and $1961 .^{1}$ On each occasion the idea was opposed by the full-time executive officials of the Union, and defeat for the resolution was an almost automatic consequence. Within the National Union of Seamen the full-time officers are very powerful, and a close examination of the Union AGM Reports over a twenty-five year period produced not a single case in which "official" policy was defeated. ${ }^{2}$

1 The fate of various resolutions on Shipboard Representation at the NUS Annual General Meetings was as follows:

1943: Defeated by 36 votes to 1 vote (AGM Report 1943, pp. 118-121);

1945: Remitted to Executive Council (AGM Report 1945, p. 103);

1946: Referred to Executive Council (AGM Report 1946, pp. 130, 139);

1947: Defeated by 62 votes to 16 votes (AGM Report 1947, pp. 136-139);

1948: Defeated by 71 votes to 12 votes (AGM Report 1948, pp. 118-126);

1949: Withdrawn (AGM Report 1949, pp. 122-124);

1951 : Defeated by 48 votes to 3 votes (AGM Report 1951, pp. 124-125);

1956: Defeated by 45 votes to 2 votes (AGM Report 1956, pp. 145-150);

1961 : Defeated by 71 votes to 27 votes (AGM Report 1961, pp. 198-216).

2 The power of permanent full-time union officers representing, in a "closed shop" Union, with an itinerant labour force, is obviously greater, in relation to the membership, than the power of a similar official who has to persuade members to join the union, and who can be called to account for his "stewardship". In the National Union of Seamen the tendency toward oligarchical control is strengthened by a number of formal rules. Up to fifty per cent. of the delegates to the AGM could be full-time officials - these had full voting rights. The only experienced lay-men in the Union, the seagoing members of the Executive Council had no 
Merchant seamen could not follow the example of shore workers and set up unofficial shipboard union representation on similar lines to the unofficial shop steward. The power of a ship's Master under the Merchant Shipping Acts and the high labour turnover of ships crews militated against unofficial representation except in very rare cases and with the agreement of the Master. To challenge the authority of the Master of a ship was to court disaster. Any seaman doing so ran the risk of being summoned under the Merchant Shipping Act for "insolence to an officer" and being "logged" for the offence. For such an offence he could be fined by the Master without reference to any court, and/or be given a "bad discharge" in his seamen's book and the risk of losing seagoing employment. The only safe way of making a protest was through the head of each shipboard department or by "all hands" presenting themselves at the Captain's door so that no one individual could be singled out for victimisation. For these reasons it was imperative to have the official agreement of the Union and shipowners for any scheme of shipboard representation.

\section{THE ARGUMENTS AGAINST SHIPBOARD REPRESENTATION}

The stated reasons of union officials against shipboard representation varied over time and were often contradictory. It was argued that such activity would result in "blacklisting" and in men losing their jobs. ${ }^{1}$ That the present system was working well and seamen should use the services of union officials and attend branch meetings more often. ${ }^{2}$ Ship's committees or delegates "were nothing more than attempts to undermine the work of the Union", 3 and, "such committees were responsible for misleading the rest of the members of the crew." This view of unofficial shipboard committees, from Mr Percy Knight, the Union National Organiser, was in direct contradiction to the views expressed by Mr Thomas Yates, the Acting Assistant General Secretary. He argued that "an unofficial committee could do a good job, but the moment it becames an official committee it is dangerous." 5 Yet both

AGM voting rights unless they also represented a Union Branch. - This was changed at the Rules Revision Conference 1967 and EC members now have AGM voting rights ex officio.

I National Union of Seamen - Report of Proceedings at the Annual General Meeting: 1943, p. 120 (Mr T. Yates, NUS National Organiser).

2 A fully-paid-up member of the NUS could attend any branch meeting but the possibility of doing so was severely limited for seafaring men because of absence from the United Kingdom.

3 NUS-AGM Report: 1945, p. 103 (Mr C. Jarman, NUS Acting General Secretary).

4 Ibid. (Mr P. Knight, NUS National Organiser).

5 Ibid. (Mr T. Yates, (now) Acting Assistant General Secretary). 
these officials were speaking against the idea of shipboard union representation. ${ }^{1}$ Further points were - that a committee or ships' delegate "who has the power of persuasion is very often able to bring about a state of affairs that the Executive Council [...] could not accept", and the Union might be brought into disrepute. It was reasonable to have shop stewards ashore because the whole organisation was ashore, "and you can bring those people to a branch meeting or to an Executive meeting", but with seafarers the union could not control the situation in this way. ${ }^{2}$ No shore establishment was governed by a Merchant Shipping Act, "and you know what the powers of the Master are when he is at sea". ${ }^{3}$

Fear, of power invested in the Master of a vessel, by virtue of the Merchant Shipping Acts, and the possibility of formal union shipboard representatives being black-listed, seem curious arguments to use against having shipboard representation. If these things were true for a formalised system of representation, supported by the Union, they would appear to be even more true for informal representatives without any union support.

The most important argument of full-time officials against shipboard representatives was on the basic question of union control. This, in various guises, is a recurring theme of the "official line" in AGM debates. ${ }^{4}$ Union officials were afraid of losing control to hot-heads or subversive elements. The problem was not without substance. There are obvious difficulties for a union organisation which is concerned with a membership permanently spread across the surface of the globe. It is difficult to maintain any degree of continuity, to maintain communications with and collect dues from, a peripatetic labour force with a high labour turnover. The problem of controlling "voluntary" work-place representatives was a more difficult and complicated problem for the National Union of Seamen than for a shore-based Union - and, as we have seen, shore based trade unions have not been without problems in their attempts to control shop floor representatives.

\footnotetext{
1 It is difficult to understand what $\mathrm{Mr} \mathrm{T}$. Yates meant by supporting unofficial committees except perhaps that "unofficial committees" did not involve the official union in any responsibility for its actions and, under shipboard conditions, could have only very limited authority. The cynical view might be that any argument was permissible so long as it was against the idea of shipboard representatives.

2 NUS-AGM Report: 1947, p. 138 (Mr T. Yates, (now) Acting General Secretary).

3 NUS-AGM Report: 1945, p. 149.

4 NUS-AGM Reports: 1943, p. 121; 1945, p. 103; 1947, p. 138; etc.
} 
THE ARGUMENTS IN FAVOUR OF SHIPBOARD REPRESENTATION

The arguments used in favour of shipboard representation by seagoing union members, were: that it would ensure a more democratic Union, ${ }^{1}$ and would help to maintain contact between members at sea and the Union, particularly members on long voyages. ${ }^{2}$ A Ship's Committee might prevent victimisation ${ }^{3}$ and could bring about greater harmony between workmen and employer. ${ }^{4}$ It could help to bring about a more co-operative spirit amongst ships' crews and make the Union more attractive to members. ${ }^{5}$ Shipboard representatives would help to prevent disputes developing. ${ }^{6}$ They could educate members in trade unionism ${ }^{7}$ and assist crew members in the interpretation of the National Maritime Board Book (this is a complex summary of agreements between owner's and unions), and to understand the Merchant Shipping Acts. ${ }^{8}$ A ship's delegate could act as witness for seamen being disciplined under the Merchant Shipping Acts or for offences against company regulations. ${ }^{9}$ There were plenty of dependable seamen who would like to do the job, and take a more active part in Union affairs, ${ }^{10}$ and it was terrible to suggest that seamen had not the intelligence and integrity to represent the Union to which they all belonged." "If shore people could have shop stewards, responsible shop stewards, then why not seamen?"12

Many of the points made by the seagoing delegates were normal practice in trade unions ashore. The hopes for greater participation by ordinary members in the work of the Union had plenty of room for application in the National Union of Seamen. The Union's close working relationship with the Shipping Federation, on the supply of seamen for allocation to jobs, and on various disciplinary functions under the Established Service Scheme, and a seemingly total concern with the collection of union dues, on the few occasions when Union Official and ordinary member had face-to-face contact, had created an attitude of

1 NUS-AGM Report: 1943, p. 120 (Letter from Mr P. Murphy).

2 NUS-AGM Report: 1945, p. 101 (Mr J. Grey, Delegate for Tower Hill Branch).

3 Ibid. AGM Report: 1947, p. 137 (Mr Davis, Delegate for Port Talbot).

4 NUS-AGM Report: 1948, p. 119 (Mr B. J. Regan, Delegate for Southampton), and p. 123 (Mr J. McGurk, Victoria \& Albert Dock (London)).

5 Ibid., p. 121 (Mr J. O'Keefe, Executive Council).

- Ibid., p. 122 (Mr R. J. Wheatley, V. \& A. Docks).

7 Ibid., p. 123 (Mr J. McGurk, V. \& A. Docks).

${ }^{8}$ Ibid., p. 125 (Mr J. Gray, Tower Hill Branch).

- NUS-AGM Report: 1956, p. 146 (Mr D. MacDonald, Southampton).

${ }^{10}$ NUS-AGM Report: 1961, p. 199 (Mr D. Macauley, Glasgow).

11 Ibid., p. 199 (Mr J. Kenny, Liverpool).

12 AGM Report: 1948, p. 123 (Mr J. McGurk, V. \&. A. Docks). 
almost nihilistic apathy amongst ordinary members toward the formal affairs of the Union. All lower deck ratings had to be in the Union, ${ }^{1}$ because of a "closed shop" agreement between the NUS and the Shipping Federation. This management supported closed shop agreement, combined with a union power structure making it almost impossible for seagoing members to effect any change in Union policy, and the Bridlington agreement of the TUC, (which forbids a union member the right of transfer to another union, if the original union does not give permission) preventing members from voting "with their feet", made seafarers virtual prisoners of a combined union-employer bureaucracy. In these circumstances a shipboard representative would have a difficult task "selling" the Union, but he might improve the situation at the workplace.

One important motivation in the pressure for seagoing "shop stewards" appears to have been a feeling of resentment by seafarers against the authorative paternalism of their industrial environment: an objection to being treated like children and not as men. They were "dependable" and did have "integrity" and "intelligence" and could do a "responsible" job. "If shore people could have shop stewards, responsible shop stewards, then why not seamen?"

The claim that a shipboard representative could prevent "victimisation" had very limited application within the framework of legal sanction of the Merchant Shipping Acts. Under these Acts the Master of a vessel has almost absolute power over his crew. If the Master of a vessel chose to "turn a blind eye" to an offence by one crew member, and penalised another for the same offence, there would be little that any shipboard representative could do. This would also be the case if the Master chose to favour a crew member by indulgency, over regulations etc., but did not allow the same indulgency to others. Under the Merchant Shipping Acts the Master has the legal authority to make such decisions, and a long tradition supported his right to autocratic authority. For a scheme of shipboard representation to work as efficiently as the supporters hoped, it would require a very different environmental framework from that provided by the Merchant Shipping Act of 1894 and subsequent amendments.

In summary, the main expectations of the advocates of shipboard representation were:

a) It could improve the attitudes of ordinary members of the NUS toward the Union and encourage more active participation.

${ }^{1}$ Membership of the National Union of Seamen is compulsory for all "lower deck" ratings. Deck and Engineer Officers, and Radio Officers, have their own unions. Neither of these were "closed shop" or concerned directly in the pressure for Shipboard Representation. 
b) That it would provide some protection for lower-deck seamen, and might avoid the development of disputes - particularly during long absences from the UK, on long voyages of up to two years, when minor disputes could fester and cause trouble among the crew.

c) It would bring the industrial situation of British merchant seamen a little more into line with conditions already enjoyed by workers ashore, and in the merchant shipping fleets of foreign nations.

\section{THE UNOFFICIAL STRIKE BY MERCHANT SEAMEN : 1960}

After the 1956 Annual General Meeting there were no further resolutions on shipboard representation until the AGM of 1961. Before that date the British shipping industry had to deal with a major unofficial strike. All the seamen supporting the dispute were members of the National Union of Seamen, but the official Union organisation was in strong opposition to the unofficial action. The dispute began in Liverpool, over a disciplinary measure concerning three crew members of the Cunard Line vessel Carinthia, ${ }^{1}$ but it spread rapidly to other ports - not as an issue of sympathy - but as a general show of discontent with conditions of employment in the industry.

The strike took place in two stages, from July 6th-21st and from August 10th to September 26th, 1960. The Ministry of Labour Gazette reported that 5,000 men took part in the first phase of the dispute and 4,000 in the later period. ${ }^{2}$ As the strike developed the seafarers involved began to draw up impromptu lists of demands, one of these was for "shop stewards on all ships". ${ }^{3}$ An unofficial pressure group, the National Seamen's Reform Movement, founded in the early stages of the strike to co-ordinate action in the various ports, issued a pamphlet, $A n$ Important Message to the Merchant Seamen of Great Britain. It listed five demands, and after the first priority of improved wages, hours and overtime, they made the demand for "Shipboard representation by ship's delegates". ${ }^{4}$

The strike of 1960 was a much bigger affair than anything the industry had experienced for nearly fifty years, since the maritime strikes of 1911. There had been a number of small unofficial strikes in the inter-war years, and two post-war disputes, in the years 1947 and 1955. In both these latter disputes the issue of shipboard representation had been a strike slogan. ${ }^{5}$ Like its predecessors, the strike of 1960 gained

${ }^{1}$ Liverpool Echo, July 8, 1960.

${ }^{2}$ Ministry of Labour Gazette, August 1960, p. 345, and October 1960, p. 417.

${ }^{3}$ The Times, July 15, 1960.

4 National Seamen's Reform Movement - London, August 2, 1960.

- Southern Daily Echo (Southampton), June 7 and 8, 1955. 
no concession from shipowners' or union, but on this occasion there was a difference; the unofficial pressure group, the National Seamen's Reform Movement, continued in existence. The Times commented:

"The seamen's strike seems likely to leave behind it another of those more or less permanent unofficial bodies, the Seamen's Reform Movement, which are to be found in an increasing number of major industries challenging the authority of the elected Union leaders and in most cases inciting and living on discontent. Responsible to no-one for their actions or their funds, they present a problem which will have to be tackled by the unions or the Government.

But if they provoke to renewed activity a union which has been resting on its oars, they cannot be said to serve no purpose."1

\section{RETIREMENT AND DEATH: NUS ELECTIONS}

In December 1960 Sir Thomas Yates retired from the post of General Secretary, and Mr Jim Scott, a man with the reputation as a radical, took over. The NSRM supported Scott's candidature for General Secretary, but after his election the new General Secretary made it clear that he would have no truck with the "Reformers". There were four resolutions on the agenda of the 1961 AGM demanding shipboard representation, but Scott threw his weight against the idea. He ensured the vote of every full-time official, against the composite resolution on shipboard representation, by a bold and threatening statement. "I will dismiss every official, or the vast majority of them, the day that ship's delegates come into the British Mercantile Marine..."2 To the older full-time Union Official, used to a sedentary mode of work, or his younger married colleague, the possibility of losing their union jobs and having to return to life at sea would not be a pleasant prospect. The resolution on shipboard representation was defeated by 81 votes against and 19 in favour, ${ }^{3}$ and it is unlikely in the circumstances that any of the latter group were full-time union officers. ${ }^{4}$ The reason for Scott's apparent change of attitude may be that he intended to prove himself "boss" of the union and not a "weak" leader. On other issues

1 The Times, September 27, 1960. Emphasis by the author.

2 NUS-AGM Report: 1961, p. 205.

3 Ibid., p. 209.

4 The practice of full-time officials of trade unions voting at conference appears to be quite common in British trade unions. What is unusual in the case of the NUS is the proportion of full-time officials to lay members in the make-up of the Delegates to the Annual General Meetings. This high proportion combined with a generally inexperienced membership lent itself to possible abuse. 
such as wage-claims, he remained more militant in approach than his predecessor.

Jim Scott died on January 21, 1962, after only a year in office, and it is perhaps some measure of the power of the General Secretary within the National Union of Seamen, that by April 27, three months after his death, and only six months after the defeat of the resolution at the 1961 AGM the NUS Executive Committee decided to review the question of a scheme for seagoing union representation. ${ }^{1}$ After the death of Scott, Mr Bill Hogarth took over as Acting General Secretary. $\mathrm{He}$ was also one of the candidates in the election for the vacant General Secretary position. There were three other candidates in the field; one of these was Mr Jim Slater, a seagoing member from South Shields, and an active NSRM man. The other candidates, like Bill Hogarth, held official positions in the Union. The election for General Secretary of the National Union of Seamen is by postal ballot spread over a period of six months, ${ }^{2}$ and in the election following the death of Jim Scott the voting took place from March 12, to September 11, 1962. The decision by the NUS Executive Committee to review the question of shipboard representatives, "in the light of discussions which have been going on for some time among the Executive Officers", ${ }^{3}$ in the early period of the election campaign, must clearly be seen as an attempt to win support for the candidature of the Acting General Secretary. It also removed a key issue from the election platform of the National Seamen's Reform Movement. In the event Bill Hogarth won the election by a clear majority of total votes cast, with Jim Slater as "runner up", in the next highest position. At the time of this election the NUS had a "gerontocratic" system of voting, giving one vote for one year of membership, two votes after five years, three votes after ten years and four votes after fifteen years of membership and it is possible that a large proportion of young seamen with only one vote, voted for Slater. ${ }^{4}$

The defeat of Slater was a hard blow for the Reform Movement,

1 The Seaman, May-June 1962, pp. 60-61.

2 Rules of the National Union of Seamen, 1957, Rule 22, Clause 2, p. 46.

The Seaman, May-June 1962, pp. 60-61.

Ballot papers sent out 30,032

Ballot papers returned $\quad 17,167$

Ballot papers spoiled

Ballot papers returned blank

124

399.

\begin{tabular}{lr} 
Hogarth & 30,897 \\
Slater & 9,855 \\
McDaid & 2,547 \\
Arnold & $\mathbf{1 , 8 8 4}$ \\
\cline { 2 - 2 } \multicolumn{1}{c}{ Total votes } & $\mathbf{4 5 , 1 8 3 .}$
\end{tabular}

The gerontocratic voting system was finally abolished in the Rules Revision Conference in 1966 as a result of general discontent with the system - the only one of its kind in any British trade union. The conflict between the NUS and the NSRM had directed a good deal of publicity to the system and brought it into disrepute. 
though perhaps not unexpected by the more realistic members. For a rank-and-file candidate to poll nearly 10,000 votes was no mean achievement, but the hard fact remained that power had been retained by the Union oligarchy. The Reform Movement newspaper, The Fo'c'astle, put a brave face on things but this defeat on top of financial problems and other internal difficulties caused fatal cracks in the organisation. In November 1962 The Fo'c'astle made its final appearance; it claimed "Victory for the Movement". The Movement, it said, had provided the spur for the 44-hour week, a $£ 4$ a month increase in wages and, above all, for "SHIP'S DELEGATES". "It now follows that with the basic policies of the MOVEMENT being fully accomplished, it brings the activities of the MOVEMENT to a logical suspension."

The NSRM could claim most of the credit for the Union's decision to adopt a system of Shipboard Representation. After the AGM of 1961 had turned down any suggestion of ship's delegates, "When all but a few officials applauded", the Reform Movement organised a "petition" in accordance with NUS Rules and two thousand seamen signed this in the 28 days which the rule allowed. Under rule a matter decided at the AGM of the Union could be challenged by any one thousand members who presented "to the General Secretary, within 28 days from the date on which the meeting was held, a written requisition signed by them specifying a decision which had been so taken and demanding that a poll in writing to all members of the Union be taken on the decision." No mention is made of this "written requisition" submitted on shipboard representation, in the official journal of the NUS. But there is little doubt that this pressure, the death of Jim Scott, and the need of the little known Bill Hogarth for a popular "platform" in the election campaign for General Secretary, caused the Union to accept the idea which had been so overwhelmingly defeated the previous year. The Rule and Clause which the NSRM had used in creating the pressure for shipboard representation had never been used in the previous history of the Union. Its use by the Reform Movement, effective as it was on the particular issue, also had the effect of attracting attention to the Rule. At the Rules Revision in 1962 it was deleted from the Rule Book on the recommendation of the Rules Revision Committee.

SHIPBOARD REPRESENTATION BECOMES NUS POLICY

At the 1962 Annual General Meeting no less than nine branches had submitted resolutions in favour of shipboard representation. After a long debate, repeating many of the previous arguments on both sides of 
the case, and without any organised "official" opposition, the following resolution was carried with 67 votes for and 31 votes against. ${ }^{1}$

"This A.G.M. adopts in principle the policy of union representation on board ship and instructs the Executive Council to draw up such regulations as it may deem necessary for the introduction and control of an effective system of Shipboard Representation. Such a system shall provide that any duly elected ship representative shall act within the regulations laid down by the Executive Council and any offence or infringement of such regulations shall be regarded as a breach of union rules."

The National Union of Seamen had adopted the principle of shipboard representation but the shipowners remained unconvinced. In the November-December issue of The Seaman, Bill Hogarth made what appeared to be a cautious statement when he said it would be, "at least six months before the first official ship representatives can be elected under the Union Scheme". In the event his statement turned out to be almost wildly optimistic. At a meeting of the National Maritime Board, on February 21, 1963, the shipowners' made it very clear that they did not like the idea of having shipboard representatives. Bill Hogarth commented, "we are all disappointed at the shipowners' dislike of our scheme. [...] At the same time we can congratulate ourselves that our arguments have had sufficient force to persuade these Victorian-era ship bosses that the subject is one worthy of further consideration."2 A Joint Working Party was set up to examine the question of officerrating relationships and to review complaints procedures. The end product of the Working Party was the acceptance of a formal "Complaints Procedure" for the industry, in July, 1963.

Prior to 1963 a British merchant vessel had no formal procedure for pressing crew complaints. The informal procedure varied from ship to ship. On small vessels the individual would be likely to make his complaint personally to his departmental officer or, on very rare occasions to the Master. On larger vessels the head of department or section, for the deck department the Bosun, might take on the task of passing on the "deck crowd" "gripes" to the "old Man" or responsible officer. On some ships the entire crew of ratings, or ratings from a particular department, would assemble at the foot of the navigating bridge and ask to see the Master. Strictly interpreted this could be very close to being an offence under the MSAs, but if it was done in a quiet and respectful manner it served the purpose of minimising the risk of

1 NUS-AGM Report: 1962, pp. 127-138 and 144-148.

2 The Seaman, March-April 1963, p. 27. 
victimisation. Any unofficial spokesman acting alone ran the risk of being singled out as a trouble maker and "sea lawyer". The new procedure set out a formal approach for the individual making a complaint, which followed the pattern of the shipboard organisational hierarchy, from section to departmental head to the Master and the possibility of appeals being heard ashore. It also made the final point that:

"It must be clearly understood that no-one making a complaint in good faith and in accordance with the foregoing procedure will be penalised in any way for making the complaint." 1

The fact that it was considered necessary to insert this clause in the new Complaints Procedure is implicit recognition that fear of victimisation might exist.

A complaints procedure without the right to formal representation was not what NUS members had fought for, and strong pressure for shipboard representation continued. A letter in The Seaman, from a West Hartlepool seafarer, made the point:

"I believe that most of our union members will see this new complaints procedure in the same light as my friends and I nothing more than a 'Milk Sop' to retard or even destroy our chance of ever having the democratic right of Shipboard Representation."2

Four resolutions on the agenda of the 1964 AGM demanded more forceful action to implement the union policy of Shipboard Representatives. The Union did continue to press the issue, but is was not until May 1965 that the shipowners' side of the National Maritime Board (the Joint Industrial Council for the Shipping Industry) finally agreed to recognise a scheme for shipboard representation. This dramatic "victory" announcement was made by the Union General Secretary on the first day of the 1965 Annual General Meeting.

The scheme began cautiously with a pilot scheme to demonstrate to the owners that the NUS plan "to extend the Union shipboard level is a sound one". ${ }^{3}$ The first vessel to operate the scheme was the Canadian Pacific Line vessel, Empress of England, sailing out of Liverpool on the North Atlantic Service. The shipowners' must have found the results of this pilot scheme satisfactory and with their co-operation the scheme

1 The National Union of Seamen, Shipboard Handbook, p. 24.

2 The Seaman, October 1963, p. 162.

3 The Seaman, September 1965, p. 200. 
has been adopted on some 350 British vessels. ${ }^{1}$ Even so, at this rate of progress, it will be ten years or more before all British flag vessels under National Maritime Board agreements are within the scheme. ${ }^{2}$

\section{THE SHIPBOARD LIAISON SCHEME ${ }^{3}$}

The purpose of the agreed Shipboard Liaison Scheme is:

a) To establish a procedure for avoiding disputes; and

b) To strengthen Union member relationships, taking Union democracy down to ship level.

The first of these points was covered by the formal "Complaints Procedure" introduced in 1963. It is important to note that under the Shipboard Liaison Scheme adopted in 1965 "the liaison representatives have no rights under the Complaints Procedure other than as individuals and, therefore, cannot accompany or represent members when taking up matters, other than at the express request of the Master or officer concerned and with the consent of the individual members involved." Not only have the liaison representatives no right to represent members under the Complaints Procedure but it is also no part of their duties to "adjudicate on the interpretation of NMB agreements; any question of interpretation must be referred to the Union through the appropriate full-time officials."

The liaison representatives must take no industrial action, and they are expected to co-operate with the Master and officers' in the efficient operation of the ship. Their main positive functions are to inform and advise members of facilities available and encourage their use, "to act in the best interests of the Union and its members", and, "to keep the Union informed of happenings on board ship outside the normal". These tasks are of a "voluntary" nature and, "liaison representatives must carry out their duties outside their own working hours."

To qualify for the NUS list of "accredited potential liaison representatives" a member "must have at least five years' continuous Union membership and five years' sea service"; be at least 23 years of age, with a clear record of conduct for the year before; and have taken, or be willing to take, a Union training course.

If a ship is selected for the liaison scheme, the full-time Union Official responsible for the scheme in that particular port, appoints one NUS member from the crew to act as Convener. He will normally be

1 NUS-AGM Report: 1968. (This is out of more than 2,000 vessels sailing under the "Red Ensign".)

2 The factual information of this Scheme is from: National Union of Seamen - Shipboard Handbook - A guide to N.U.S. Shipboard Liaison Representatives.

NUS - Shipboard Handbook, pp. 14-19. 
"a member of long-standing and experience". Within seven days of sailing from the first port the Convener must call a meeting of NUS crew members and arrange for the nomination of candidates for the post of Liaison Representative(s) and for any ballot. These nominations must be on the union list of "accredited potential liaison representatives", or, if there are no "accredited" members amongst the crew, non-accredited candidates, "subject to his endorsement by the Union". The Convener himself is not precluded from standing as a candidate for the position of Shipboard Liaison Representative.

On a vessel with an NUS crew of thirty, or less, the scheme allows one representative to cover all departments. On larger vessels there may be a representative for each department, with an assistant representative if the department has more than 100 NUS members. The election of liaison representative(s) is by secret ballot, and no election is valid unless two-thirds of the eligible membership have voted. "If less than two-thirds of such valid votes are cast, this will be taken to mean that no liaison representative will be elected for the ship or department concerned for the particular voyage." If one-third or more of the crew/ department become dissatisfied with the conduct of their representative, the Convener will call a meeting to consider the matter, and a new election may be held.

\section{CONCLUSION}

In making an assessment of the shipboard liaison scheme we have to keep in mind the special conditions of seafaring life. The ship is a "total institution"; the seafarer works, eats, sleeps; has his total social existence within the limits of the shipboard community. The Merchant Shipping Act of 1894, Sections 220-238, impose conditions of discipline which are justified on the grounds of the need for "prompt and coordinated action by the crew on any occasion of emergency $[. .$.$] in the$ interests of efficiency $[. .$.$] for preserving law and order in the confined$ and inescapable conditions." 1 The shipboard liaison scheme has to operate within this legal framework, and in an industry with a long tradition of the Master in complete command of his ship, with absolute final authority over the workplace. Within these limits a shipboard representative could only be allocated very circumscribed functions.

The Shipboard Liaison Scheme which was agreed between the National Union of Seamen and shipowners' representatives, does not challenge established shipboard authority. It gives no additional protection to the seafarer, at the workplace, from the possibility of arbitrary "justice"

1 Final Report of the Court of Inquiry into certain matters concerning the Shipping Industry, February 1967, HMSO Cmnd 3211. 
by the Master. The major functions of the liaison representative are of a co-operative and consultative nature. It conceded no right of a seaman to representation under the new Complaints Procedure, or when a seaman is facing disciplinary charges under the relevant sections of the Merchant Shipping Acts. It does not prevent "the use of legal sanctions to compel acceptance of working conditions which free agents would endure [and] leads one to question the credibility of grievance settlement procedures at the place of work." 1 This continued "authoritarianism" in shipboard life, in juxtaposition to the "permissive society" ashore, may be an important factor behind the high labour turnover in the maritime industry.

Taking into account the very limited role allocated to shipboard representatives, the conditions attached to the Liaison Scheme appear overcautious by the standards of trade union practice in industry ashore. Workers ashore would be unlikely to tolerate the intrusion of a full-time union official in the election of workshop "Convenor", or the limitation in the choice of "Shop Steward" or "Consultative Committee Representatives" to an official list of "accredited potential" candidates. In the Shipboard Liaison Scheme the choice is limited still further by the additional qualification of "five years continuous union membership". Seafaring is a young man's profession; the average length of a seagoing career is under ten years, ${ }^{2}$ and the average for ratings is probably less. Many seafarers have short periods ashore, because of marriage or other domestic reasons, or simply to try a job ashore. Under the five year continuous membership rule these could be prevented from becoming "accredited" to hold office under the scheme.

The Shipboard Liaison Scheme, introduced in 1965, after years of pressure from seagoing men in the British Merchant Navy, falls short of the hopes expressed by its early advocates. The shipboard power structure remains unchanged, and the scheme provides no countervailing power. The scheme does make possible the formal co-operation between officer and rating which may lead to a better understanding of each other's position. This, combined with the tendency towards technically more complex merchant ships, requiring a more highly skilled lower-deck labour force, may lead to a lessening of the gulf, the social distance, between officer and rating. The Union should also gain a more active and informed membership as a consequence of the improved communication with membership at ship level. The Union Education Programme provides regular training courses for Liaison

1 J. Kinahan, Unpublished Evidence to the Committee of enquiry into certain matters concerning the Shipping Industry, Chairman Lord Pearson, 1966.

2 "The British Shipping Industry", in: Planning (PEP), Vol. XXV, No 437, 16 November 1959, p. 212. 
Representatives, and this training, supported by The Seaman, a union journal of high quality, is moulding a work place representative system capable of responsible and well informed leadership. With goodwill on both sides of the shipping industry, and a new Merchant Shipping Act (due in the current Parliamentary Session), a major improvement in the industrial situation of merchant seamen is possible. It will be a tragedy for the shipping industry if this opportunity is missed, but the Merchant Shipping Bill, published in July 1969 and revised in October, leaves little room for optimism. The lesson that restrictive or repressive legislation is likely to be counter-productive to its intentions has not yet, it seems, been learned.

A ship at sea is a unique work place with special difficulties for organisational change or modifications in traditional management prerogatives, but such changes are imperative if the industry is to remain an attractive career prospect for high calibre personnel against competition from shore industry in conditions of full employment and the varied attractions of a permissive society. The decline in the number of passenger vessels, which carry a large crew, and the trend towards technically more complex ships manned by a relatively small number of specialist personnel, should diminish the need for the traditionally hierarchical "mechanistic", method of shipboard organisation, based upon legal sanctions. Highly qualified specialists, experts in their own right, are likely to function more efficiently and to take personal initiatives in a more fluid "organic" system of organisation allowing consultation between equals. A system of shipboard organisation with less divergent status, and a greater expectation of individual responsibility and self-discipline, should meet the needs of a modern shipping industry, and make possible more efficient use of labour resources. Without such changes an effective Shipboard Liaison Scheme is a prime necessity to give greater balance to an authoritarian system of organisation, to provide countervailing power and the representation of "lower-deck" interest. 